REVISTA DE DERECHO UNED, NÚM. 17, 2015

\title{
ORDEN PÚBLICO Y SEGURIDAD CIUDADANA. MODIFICACIONES NORMATIVAS
}

\author{
PUBLIC ORDER AND PUBLIC SAFETY. \\ REGULATIONS MODIFICCIONES
}

ALBINO FERNÁNDEZ FERNÁNDEZ

Doctorando UNED

\begin{abstract}
Resumen: La aprobación de la segunda ley Orgánica de Protección de la Seguridad Ciudadana, que deroga la anterior, y entrará en vigor el día 1 de julio de 2015, a excepción de la disposición final primera, sobre rechazo en frontera, y sólo para Ceuta y Melilla, permite un análisis de las diferencias existentes entre el Orden Público tradicional y la actual Seguridad Ciudadana. Analizamos el Orden Público desde sus tres acepciones: Como límite a la autonomía de la voluntad, como imposición del poder ejecutivo, y como derecho fundamental de los ciudadanos para poder ejercitar sus derechos y libertades y disponer de la tranquilidad necesaria que les permita materializar su proyecto de vida. La seguridad Ciudadana está encomendada constitucionalmente a las Fuerzas y Cuerpos de Seguridad. Pese a las críticas iniciales al proyecto de Ley Orgánica de Protección de la Seguridad Ciudadana, finalmente, los cambios realizados son más bien pocos y de escasa entidad.
\end{abstract}

Palabras clave: Orden Público, Seguridad Pública, Seguridad Ciudadana; ley mordaza.

Abstract: The adoption of the Second Organic Law of Protection of Public Safety, which repeals the former Law and will enter into force on July 1st of 2015, except for the first final provision, on border rejection, and only for Ceuta and Melilla, allows to analyze the differences between traditional Public Order and the current Public Safety. Public Order is analyzed from its three meanings: As a boundary for the autonomy of 
will; as an imposition on the executive power; and as a fundamental right of citizens to exercise their rights and freedoms and to have the necessary peace of mind to enable them to materialize their life project. Public safety is constitutionally entrusted to the law-enforcement agencies. Finally, despite initial criticism of the draft Organic Law of Protection of Public Safety, changes are rather few and minor.

Keywords: Public Order; Públic Safety; Citizen Security; gag rule Recepción original: 29/06/2015 Aceptación original: 31/07/2015

Sumario: I. Orden Público y Seguridad. II. Orden Público como atributo de la soberanía o poder ejecutivo. II. A. Leyes Administrativas de Orden Público. III. El orden público como límite a la autonomía de la voluntad; normas imperativas, principios esenciales de la comunidad y buenas costumbres. IV. Derecho fundamental y subjetivo de la Seguridad. La seguridad ciudadana y la seguridad pública. IV. A. El derecho fundamental de la seguridad. IV. B. La Ley Orgánica de Protección de la Seguridad Ciudadana de 1992. IV. C. La Ley Orgánica 4/2.015, de 30 de marzo, de Protección de la Seguridad Ciudadana. V. Conclusiones.

\section{ORDEN PÚBLICO Y SEGURIDAD}

La Constitución de 1.812 menciona el orden público al señalar que «la potestad de hacer ejecutar las leyes reside exclusivamente en el Rey, y su autoridad se extiende a todo cuanto conduce a la conservación del orden público en lo interior, y a la seguridad del Estado en lo exterior» ${ }^{1}$.

El Código Civil de Napoleón de 1804 afirmaba en su artículo 6. ${ }^{\circ}$ que «no se pueden derogar por convenios particulares las leyes que interesan al orden público y las buenas costumbres»².

La Constitución de 1978 dispone que «se garantiza la libertad ideológica, religiosa y de culto de los individuos y las comunidades sin más limitación, en sus manifestaciones, que la necesaria para el mantenimiento del orden público protegido por la ley» ${ }^{3}$ y que «...En

${ }^{1}$ Constitución de 1812, artículo 170.

${ }^{2}$ On ne peut déroger par des conventions particulières, aux lois qui intéressent l'ordre public et les bonnes moeurs. El Código Civil Francés, después de más de dos siglos, ha sufrido toda una serie de cambios; sin embargo, el sexto de sus artículos permanece intacto.

${ }^{3}$ Artículo 16.1 de la CE (Constitución Española de 1978). 
los casos de reuniones en lugares de tránsito público y manifestaciones se dará comunicación previa a la autoridad, que sólo podrá prohibirlas cuando existan razones fundadas de alteración del orden público, con peligro para personas o bienes» ${ }^{4}$.

También el artículo 17.1 de nuestra Constitución dispone que «Toda persona tiene derecho a la libertad y a la seguridad»: y la Declaración Universal de los Derechos Humanos, aprobada por la Asamblea General de las Naciones Unidas el 10 de diciembre de 1948, afirma en su artículo 3 que «todo individuo tiene derecho a la vida, a la libertad y a la seguridad de su persona»; y con anterioridad la Declaración de Derechos de Virginia de 1776, en su artículo 1 afirmaba que «todos los hombres tienen por naturaleza derecho a gozar de la vida y de la libertad, a través de la adquisición y el ejercicio de la propiedad, y a la búsqueda y la obtención de la felicidad y de la seguridad».

De los textos normativos anteriores se puede afirmar, respecto del concepto de orden público, que su significado no es unívoco; sus contenidos varían en función de la posición del observador; y las diferencias entre unos y otros son difícilmente reconducibles a un concepto unitario.

Ante la dificultad de integrar en un concepto único todas las acepciones del orden público, intentaremos clarificar las distintas acepciones.

\section{ORDEN PÚBLICO COMO ATRIBUTO DE LA SOBERANÍA O PODER EJECUTIVO}

En cualquier comunidad es deseable el orden y la paz social que permita a sus integrantes el bienestar, desarrollo y desenvolvimiento pacífico social requerido.

En este sector del ordenamiento, el concepto se vincula con la protección de una situación social concreta, imprescindible en cualquier comunidad estatal: el orden y la paz pública. El enfoque se realiza desde un aspecto negativa que se alude a la prevención y sanción de aquellos actos o conductas susceptibles de alterar el orden público y que la Autoridad y sus Agentes tienen la obligación de reprimir, sancionar y restablecer; adoptándose para ello la legislación más adecuada según la estructura de la comunidad, la época o momento, la ideología política, la fuerza dominante o institución que ostente el poder

\footnotetext{
${ }^{4}$ Artículo 21.2 de la CE.
} 
o soberanía ${ }^{5}$. Las élites dominantes procuran llevar a efecto sus proyectos de vida dentro de un orden social que ellas mismas definen e imponen. Es la respuesta a situaciones de dominio, ventaja o predomino social. El orden le es impuesto, normalmente, a las capas sociales inferiores y a disidentes o marginados de disputas políticas. Se trata de un orden social impuesto desde arriba y que el resto tiene la obligación de acatar.

El Estado absoluto fue la fuerza que se impuso al conjunto de la vida feudal mediante la expropiación progresiva de los medios políticos. Los nuevos factores económicos y sociales solamente se podían imponer en la medida en que se debilitaran y disolvían las estructuras de la organización feudal, por lo que el propósito último era propiciar su caída ${ }^{6}$.

El señor feudal o gran señor posicionaba a sus vasallos según los servicios que éste le dispensaba tanto en la guerra como en la administración. Su relación era personal y venía determinada por la conducta y relación entre ambos; la institución del vasallaje. Esas relaciones personales entre vasallos y señores feudales serán asumidas por el Estado absoluto, concentrando el poder de las relaciones personales anteriores y sustituyéndolas por el poder político. Se inicia la centralización administrativa, la lucha contra las viejas estructuras feudales y se establece el cauce para un desarrollo económico dentro de un proyecto político.

El Estado absoluto abandona las relaciones de vasallaje, servidumbre y costumbres señoriales y establece unas nuevas relaciones políticas fundamentadas en la personalidad individual como sujeto de derechos y obligaciones.

A medida que la administración gubernamental va aumentando en su forma centralizada de gobierno, se produce un retroceso de las relaciones feudales. El Estado absoluto al conseguir la capacidad para administrar de forma centralizada abandona el carácter personal de la relación y lo convierte en impersonal y objetiva.

El señor feudal disfrutaba en el feudo de cierta seguridad que le proporcionaba la vigilancia de carácter militar; pero la relación del vasallo con el señor y el vínculo de unión establecido tenían un carác-

${ }^{5}$ El Código Penal sanciona hechos contrarias al orden público. El poder ejecutivo impide la realización de actos contrarios, de forma preventiva, y sancionada administrativamente actos o conductas que perturban dicha actividad administrativa.

${ }^{6}$ UVALLE BERRONES, Ricardo; El Gobierno en Acción: La formación del régimen presidencial de la administración pública; Fondo de Cultura Económica, (FCE), Mexico, 1984, pág. 29. 
ter personal. Este carácter personal será abandonado con el Estado absoluto al garantizarse el ejercicio de la coerción sobre un espacio social.

Los Reyes Católicos desterraron a señores fronterizos, prohibieron la guerra privada, suprimieron o disminuyeron la autonomía municipal e implantaron la figura de los corregidores oficiales, asumiendo las funciones de los alcaldes, elegidos en los concejos.

Por la Real Pragmática de 9 de julio de 1500 o Capítulo para corregidores y jueces de residencia, se les atribuye competencia para prohibir la blasfemia, ciertos juegos, la usura y los «pecados públicos», así como la persecución de adivinos y malhechores, disponiendo de amplia jurisdicción para castigar los delitos, desterrar a quienes alteren el orden y ejecutar disposiciones gubernativas ${ }^{7}$.

Felipe II en su Pragmática de 1539 dictada en Toledo, se dan órdenes para perseguir a los perturbadores del orden social; se prohíben los grupos armados de más de tres personas y se establecen penas de látigo o galeras para tales conductas ${ }^{8}$.

Ante la falta de funcionarios civiles armados, la organización militar asumirá durante varios siglos el mantenimiento del orden público; y las autoridades civiles, judiciales, administrativas y políticas recurrirán al Ejército como institución competente ante resistencias, revueltas, algaradas, contrabandistas, control de caminos, libertad de circulación y del comercio, o siempre que se precise de fuerza armada o coerción para cumplir las normas instituidas.

Carlos III dictó la Pragmática Real de 17 de abril de 1774, sobre manifestaciones y asonadas políticas, y la Pragmática de 29 de junio de 1784, dirigida a los Capitanes Generales sobre la represión del contrabando.

La mayor parte de las disposiciones dictadas hasta el siglo XVIII relativas al orden público estaban dirigidas a asegurar éste en la Corte, ya fuera en Toledo o en Madrid.

Fernando VII dictó la Pragmática de 22 de agosto de 1.814 que ordenaba que las tropas del Ejército persiguieran a los malhechores y que serían juzgados por Tribunales militares permanentes, acorde con lo establecido en la Constitución de 1812 que atribuía a una fuerza

${ }^{7}$ IZU BELLOSO, Miguel J. La Policía foral de Navarra; Gobierno de Navarra, Departamento de Presidencia e Interior, Pamplona,1991, pág. 76.

${ }^{8}$ DELGADO AGUADO, Julián; La noción de Orden Público en el Constitucionalismo español, Dykinson, Madrid, 2011, pág. 47. 
militar nacional permanente de tierra y de mar para la defensa exterior del Estado y la conservación del orden interior ${ }^{9}$, y cuyo jefe supremo era el monarca, según el propio articulado de la Constitución de Cádiz. La seguridad interior y su potestad exclusiva normativa y fáctica le son atribuidas al Rey. Y, al situarse el monarca en la cúspide de la cadena del mando militar, como jefe máximo, el orden público se verá permanentemente afectado, cuando no atribuido en exclusiva, a las fuerzas militares. La potestad y autoridad del orden público corresponde al Rey, y en la Constitución de Cádiz dicho cometido se le encomienda a las fuerzas militares ${ }^{10}$.

La competencia monárquica en materia del orden público, como jefe supremo de las fuerzas militares, que continuará con semejantes o parecidos términos en las Constituciones de 1837, 1845, 1869 y 1876, será una de las causas de la intervención militar, en las tareas de orden público durante todo el siglo XIX en España, llegando a considerársele como la mayor fuerza policial ${ }^{11}$, pese a los intentos y sucesivos balbuceos de una policía civil que ya había sido reconocida e instaurada en Francia, donde también persistían en su continuidad les prévôté de marechaussée o Gendarmería, con dependencia del Ministerio de Defensa.

\section{A. Leyes Administrativas de Orden Público}

En 1867, bajo el mandato del gobierno de Narváez, se aprobará la primera Ley de Orden Público. En la misma se regulaban las situaciones del Estado normal, el de Alarma y el de Guerra. Este último correspondería la competencia a la Autoridad militar, después de ser declarado por la Autoridad Civil. Establecía, igualmente, la creación de «secciones de Orden Público», dentro de un Departamento central en el Ministerio de la Gobernación.

El 23 de abril de 1870 se promulga una nueva Ley de Orden Público que preveía los estados de Prevención y de Guerra. Para poder

\footnotetext{
${ }^{9}$ Artículo 356 de la Constitución de 1812.

${ }^{10}$ Epígrafe LXII del Discurso Preliminar de presentación del Proyecto de la Constitución de Cádiz: el soldado es un ciudadano que suspendiendo la tranquila e inocente ocupación de la vida civil va a proteger y conservar con las armas, cuando es llamado por la ley, el orden público en lo interior, y hacer respetar la nación siempre que los enemigos de afuera intenten invadirla u ofenderla.

${ }^{11}$ Así lo entienden LORENZO MARTÍN RETORTILLO en Notas para la historia de la nación de orden público, Revista Española de Derecho Administrativo, núm. 36. y MANUEL BALLBÉ «Orden público y militarismo en la España constitucional, 1812-1983, Alianza, Madrid, 1983.
} 
aplicarse, establecía la exigencia legal de suspensión de las garantías constitucionales; su artículo $1 .^{\circ}$ señalaba que «las disposiciones de esta Ley serán aplicadas únicamente cuando se haya promulgado la Ley de suspensión de garantías a que se refiere el artículo 31 de la Constitución de 1869». Como afirma Martín Retortillo «el orden público tal y como se refleja en la Ley de 1870, es un orden público que se refiere a revueltas, a asonadas, a motines, y a levantamientos populares. Es un orden público de partidas y de barricadas» ${ }^{12}$.

En 1933 se elabora una nueva Ley de Orden Público que regula los estados de Prevención, Alarma y de Guerra; y se establecen unos tribunales de urgencia para delitos contra el orden público. La novedad de la Ley de Orden Público de 28 de julio de 1933 consiste en la normalización del concepto, sin necesidad de suspensión de garantías constitucionales y cuya aplicación forma parte de las facultades ordinarias del Gobierno, que puede adoptar nuevas medidas en cualquier momento. Igualmente se produce un aumento de las conductas que pueden incluirse dentro de los actos calificados como contrarios al Orden público.

La Ley de Orden Público de 1959 mantiene el esquema de la de 1933, ampliando el concepto y los actos incluidos como contrarios al orden público.

El artículo $1 .^{\circ}$ de la Ley intenta definir el orden público al afirmar que «el normal funcionamiento de las instituciones públicas y privadas, el mantenimiento de la paz interior y el libre y pacífico ejercicio de los derechos individuales, políticos y sociales, reconocidos en las leyes, constituyen el fundamento del orden público». En el artículo segundo se señalan como actos contrarios al orden público entre otros, atentados a la unidad espiritual, nacional, política y social de España; regularidad en los abastecimientos; paros, cierres o suspensiones de empresa; tumultos; manifestaciones; desórdenes; atentados contra la salubridad; desobediencia a las decisiones de la autoridad o sus agentes o la alteración de la convivencia social.

Ya en la última etapa del franquismo se produce la creación de un órgano jurisdiccional «ad hoc», el Tribunal de Orden Público, con la misión de juzgar y reprimir los denominados delitos políticos. La Ley 54/1963, de 2 de diciembre de 1963 crea dicho tribunal que continuará hasta el año 1977. Sus funciones consistirían en el enjuiciamiento de los delitos comprendidos en el título I del Código Penal, contra la

\footnotetext{
${ }^{12}$ MARTÍN RETORTILLO y BAQUER, SEBASTIÁN R., La cláusula de orden público como límite impreciso y creciente del ejercicio de los derechos, Cívitas, Madrid, 1975, pág. 41.
} 
seguridad exterior del Estado; contra el Jefe del Estado, las Cortes, Consejo de Ministros y forma de Gobierno; los cometidos con ocasión del ejercicio de los derechos de la persona reconocidos por las Leyes; rebelión; sedición; desórdenes públicos; propagandas ilegales; siempre que obedezcan a un móvil político o social; las detenciones ilegales; sustracción de menores: allanamiento de morada; amenazas y coacciones; descubrimiento y revelación de secretos; los delitos conexos y las faltas incidentales de los delitos mencionados en los dos apartados anteriores ${ }^{13}$.

Este Tribunal conocerá también, en el supuesto a que se refiere el párrafo primero del artículo cuarenta y tres de la Ley de Orden Público de treinta de julio de mil novecientos cincuenta y nueve y con jurisdicción en todo o parte del territorio nacional al que afecte la declaración del estado de excepción, de los hechos delictivos que el artículo cuarenta y cuatro de dicha Ley señala y que atribuye al Tribunal de Urgencia.

Asumió algunas de las funciones del Tribunal Especial de Represión de la Masonería y el Comunismo y algunas que limitaban con las propias de la jurisdicción militar, ya que enjuiciaba delitos cometidos contra las Fuerzas Armadas ${ }^{14}$.

Sin el carácter de leyes administrativas, por cuanto fueron leyes penales, cabe mencionar, la Ley de Peligrosidad y Rehabilitación Social de 1970 que derogó la Ley de Vagos y maleantes de 1933 («La gandula»), que sancionaban el comportamiento de vagos, mal entretenidos, rufianes, proxenetas, homosexuales, lisiados... con medidas de internamiento, alejamiento, control gubernativo, retención e incluso reclutamiento de hasta 5 años.

\section{EL ORDEN PÚBLICO COMO LÍMITE A LA AUTONOMÍA DE LA VOLUNTAD; NORMAS IMPERATIVAS, PRINCIPIOS ESENCIALES DE LA COMUNIDAD Y BUENAS COSTUMBRES}

El orden público como límite a la autonomía de la voluntad de las partes tiene su antecedente en el Código Civil de Napoleón de 1804,

${ }^{13}$ Artículo $3 .^{\circ}$ de la Ley de 2 de diciembre de 1963, creadora del TOP (Tribunal de Orden Público).

${ }^{14}$ Por Decreto Ley del 4 de enero de 1977 se suprimió el TOP, al mismo tiempo que se creaba la Audiencia Nacional para asumir ciertos delitos que abarcaban el territorio de más de una Audiencia Provincial y cuyo fuero objetivo había sido atribuido al Tribunal de Orden Público. A pesar de que la ley 52/2007 declaró en sus artículos 2 y 3 que este Tribunal era ilegítimo, no significó la retroacción de efectos de sus resoluciones, que siguen siendo ajustadas a Derecho. 
cuyo artículo $6 .^{\circ}$, ya citado, se transcribía literalmente en nuestro proyecto de Código Civil de 1851, en su artículo 11, y que en palabras de García Goyena el orden público debía interpretarse como leyes de derecho público, ${ }^{15} \mathrm{en}$ su terminología romana en vez de la francesa. ${ }^{16}$ La denominada cláusula de orden público fue incorporada a la totalidad de los códigos civiles europeos, y a algunos americanos. Su bien jurídico protegido correspondería a los denominados de «titularidad difusa» o de la sociedad en su conjunto.

Algunos autores identifican orden público con normas imperativas; otra parte de la doctrina lo niega y contra éstos se alega que en tal caso el concepto de orden público al margen de la ley provoca inseguridad jurídica. Cabría añadir que si ya son normas imperativas positivas no sería necesaria la utilización del término de orden público, siendo suficiente el afirmar ir en contra de la legalidad, principios o normas imperativas del ordenamiento jurídico. En este sentido el Orden Público internacional se adapta íntegramente a esta acepción al considerar como tal lo dispuesto en las normas de ius cogens ${ }^{17}$.

El Código Civil hace referencia al orden público como límite a la voluntad de los particulares en los artículos $6.2^{18}$, o $1.255^{19}$, como límite a la aplicación de normas extranjeras en el artículo $12.3^{20}$, o para la concesión de la nacionalidad en el artículo $21.2^{21}$. Así entendido, el orden público es una cláusula de cierre del ordenamiento, cuya interpretación corresponderá al órgano jurisdiccional.

15 «Ius publicum».

${ }^{16}$ Acedo Penco, Ángel; El orden público actual como límite a la autonomía de la voluntad en la doctrina y la jurisprudencia. Anuario de la Facultad de Derecho de la Universidad de Extremadura, número 14-15, 1996-7, pág. 332.

${ }^{17}$ Normas de derecho consuetudinario que obligan a toda la comunidad internacional, como la prohibición del uso de la fuerza; el derecho a la autodeterminación de los pueblos coloniales; los crímenes de lesa humanidad, el genocidio, la discriminación racial, tortura o tratos degradantes...

${ }^{18}$ Artículo 6.2 «La exclusión voluntaria de la ley aplicable y la renuncia a los derechos en ella reconocidos sólo serán válidos cuando no contraríen el interés o el orden público ni perjudiquen a terceros».

${ }^{19}$ Artículo 1.255, «Los contratantes pueden establecer los pactos, cláusulas y condiciones que tengan por conveniente, siempre que no sean contrarios a las leyes, o a la moral, ni al orden público.

${ }^{20}$ Artículo 12.3 «en ningún caso tendrá aplicación la ley extranjera cuando resulte contraria al orden público».

${ }^{21}$ Artículo 21.2 «La nacionalidad española también se adquiere por residencia en España, en las condiciones que señala el artículo siguiente y mediante la concesión otorgada por el Ministro de Justicia, que podrá denegarla por motivos razonados de orden público ò interés nacional». 
Como fuente del ordenamiento jurídico, la costumbre en defecto de ley aplicable, se encuentra también limitada por el orden público y la moral ${ }^{22}$.

La dificultad de su definición viene determinada intrínsecamente y así ha sido advertido por la doctrina y la jurisprudencia, por cuanto es un concepto variable, según costumbres, territorios y momentos. ${ }^{23}$

Nuestro Tribunal Supremo recoge un concepto similar al de la doctrina alemana, «el orden público nacional está integrado por aquellos principios jurídicos, públicos y privados, políticos, económicos, morales e incluso religiosos, que son absolutamente obligatorios para la conservación del orden social en un pueblo y en una época determinada $»^{24}$.

Pese a que el orden público, es una expresión utilizada ampliamente por el legislador, «su significado no es unívoco en cada uno de los sectores del ordenamiento español; ni tampoco es igual su función en las diferentes dimensiones del Derecho internacional privado. Y esta pluralidad de significados puede generar graves dificultades al interpretar la referencia al «orden público» en un concreto precepto» ${ }^{25}$.

Afirma el profesor Acedo Penco ${ }^{26}$ que Federico de Castro se pronunció al respecto, en uno de sus trabajos, ${ }^{27}$ afirmando que desde la aparición del concepto, los civilistas «se han visto y se ven forzados a la tarea ingrata, difícil, quizás imposible, de explicar y definir lo que

${ }^{22}$ Artículo 1.3 del Código Civil, «La costumbre sólo regirá en defecto de ley aplicable, siempre que no sea contraria a la moral o al orden público y que resulte probada».

${ }^{23}$ La doctrina alemana suele definir el orden público como el conjunto de reglas no escritas, cuyo cumplimiento según las concepciones sociales y éticas dominantes se considera como condición previa indispensable para una convivencia próspera y ordenada dentro de la comunidad. Esos valores, por tanto, quedan situados fuera de la estructura jurídico-normativa. (José Luis CARRO FERNÁNDEZ-VALMAYOR; Los problemas de la coacción directa y el concepto de orden público, Revista Española de Derecho Administrativo, núm. 15, editorial Cívitas, Madrid, 1977, pág. 605).

${ }^{24}$ IZU BELLOSO, Miguel José, Los conceptos de orden público y seguridad ciudadana tras la Constitución de 1978; Revista Española de Derecho Administrativo n. ${ }^{\circ}$ 58, Cívitas, abril-junio de 1988. pág. 4 (Sentencia de 5 de abril de 1966, recogida en el Repertorio de Aranzadi con el número marginal 1684).

${ }^{25}$ GONZÁLEZ CAMPOS, Julio D. y José Carlos FERNÁNDEZ ROZAS «Artículo 12, apartado 3 del Código Civil», Comentarios al Código civil y Compilaciones forales (M. Albaladejo y S. Díaz Alabart, eds.), t. I, vol. 2, Jaén, Edersa, 1995. pág. 902.

${ }^{26}$ ACEDO PENCO, Ángel; El orden público actual... op. cit. pág. 325 y nota a pie de página 2 .

${ }_{27}$ CASTRO Y BRAVO, Federico de; Notas sobre las limitaciones intrínsecas de la autonomía de la voluntad. La defensa de la competencia. El Orden Público. La Protección del consumidor; Anuario de Derecho Civil 1982, Tomo XXXV, Fascículo IV; Ministerio de Justicia; Madrid; Octubre-diciembre 1982, pág 1.021 y ss. 
sea el orden público expresado en los Códigos civiles». De Castro expresa, entre otras, las siguientes apreciaciones: «Tratar de definir el orden público es aventurarse en arenas movedizas»; «Un suplicio para la inteligencia»; "caminar por un camino cubierto de espinas»; o «cabalgar con un caballo fogoso que nunca sabe a dónde llevará». Dichas expresiones dan una idea de la dificultad de su definición.

En la Sentencia del TC 108/1985, de 8 de noviembre, se concede un nuevo significado en el ámbito de las normas procesales, donde se afirma que este sector del ordenamiento está «... imbuido en el orden público» y en él operan los principios de «... la buena fe, la diligente actitud y la lealtad intersubjetiva, que no pueden quebrantarse por conductas interesadas y sinuosas».

Está aceptado que las normas procesales se califiquen como normas de orden público, inderogables por los particulares ${ }^{28}$.

Las normas de orden público, son constatables, también, en el ordenamiento laboral, como lo demuestran tanto la jurisprudencia como la doctrina y la referencia a las «normas de orden público» en el artículo 1.4 de la Ley 8/1980, de 10 marzo, del Estatuto de los Trabajadores.

En la exposición de motivos de la Ley de Arbitraje ${ }^{29}$ se declara que se debe considerar nulo el acuerdo arbitral contrario a las normas de Orden Público y el artículo 45.5 establece que se puede considerar nulo el laudo dictado contraviniendo el Orden Público.

El orden público se incluye en muchas otras leyes y disposiciones, así el artículo $13,1^{\circ}$, de la Ley Orgánica 4/1981, de los estados de alarma, excepción y sitio, y también el peligro de trastorno grave del orden público figura en el de la jurisdicción Contencioso-Administrativa como causa de suspensión o inejecución de las sentencias, según se dispone en el artículo 105, 2. ${ }^{\circ}$, causa 2.a, de la Ley de 27 diciembre 1956.

El Código Penal hace referencia al orden público y le dedica el Título XXII, con la denominación de Delitos contra el orden público, que abarca los delitos de Sedición ${ }^{30}$, atentados, resistencia y desobediencia a la Autoridad y sus agentes ${ }^{31}$, los desórdenes públicos ${ }^{32}$ y los

${ }^{28}$ Artículo 138-2, de la Ley de Enjuiciamiento Civil sobre celebración de actuaciones a puerta cerrada para la protección del orden público.

${ }^{29}$ Ley 36/1988, de 5 de diciembre (BOE de 07-12-1988), que deroga la Ley de 22-12-53, por la que se regulan los arbitrajes de derecho privado.

${ }^{30}$ Artículo 544 al 549 del C.P.

${ }^{31}$ Artículo 550 al 556.

${ }^{32}$ Artículo 557 al 561. 
delitos de tenencia, tráfico y depósito de armas y explosivos y delitos de terrorismo ${ }^{33}$.

\section{DERECHO FUNDAMENTAL Y SUBJETIVO DE LA SEGURIDAD. LA SEGURIDAD CIUDADANA Y LA SEGURIDAD PÚBLICA}

El constituyente establece el orden público constitucional y habilita al legislador ordinario para establecer las disposiciones necesarias para su mantenimiento. Nuestra Constitución del 78, en el artículo 16.1, estructura la titularidad del orden público a partir de una habilitación al legislador en relación con el ejercicio ilegal de determinados derechos. El artículo 21.2 establece atribuciones funcionales a la Autoridad, que no a sus agentes, para limitar el ejercicio de los derechos de reunión y manifestación, cuando supongan una alteración del orden público con peligro para personas o bienes ${ }^{34}$.

El orden público constituye, por tanto, un interés social, constitucionalmente reconocido, que pone límite al ejercicio de derechos de libre manifestación de las ideologías, convicciones religiosas o de culto y de los derechos de reunión en lugares de tránsito público y de manifestación, cuando concurran determinadas circunstancias ${ }^{35}$.

\section{A. El derecho fundamental de la seguridad}

Ya en el proyecto de Constitución española de 1873, que no llegó a ser aprobada, encabezaba el título preliminar, en la relación de los derechos naturales, con «el derecho a la vida, a la seguridad, y a la dignidad de la persona». Las demás constituciones de 1812, 1837, 1845, y 1876, conciben la seguridad en su doble dimensión de orden público interior y de seguridad exterior, como un atributo de la sobe-

${ }^{33}$ Artículo 563 a 580.

${ }^{34} \mathrm{La}$ Constitución confiere a la Autoridad, competencias ejecutivas-prohibir la reunión en lugar de tránsito público- y al legislador la capacidad normativa a la que estará sujeta la autoridad en virtud del artículo 53.1. Así, el orden público tiene como sujeto activo al legislador, como sujeto activo secundario a la Autoridad y como sujetos pasivos a los que se ven afectados por la prohibición.

${ }^{35}$ FREIXES SANJUÁN, Teresa y REMOTTI CARBONELL, José, C. La Configuración Constitucional de la Seguridad Ciudadana. Revista de Estudios Políticos Nueva Época. Núm. 87. Centro de Estudios Políticos y Constitucionales, Madrid, EneroMarzo 1995, pág. 146. 
ranía o del poder Ejecutivo ${ }^{36}$, no como un derecho fundamental de los ciudadanos.

Con la Constitución de 1.978 el concepto de Orden Público, entendido como atributo del poder durante la dictadura, fue sustituido por el de Seguridad o seguridad ciudadana, entendido como derecho fundamental de las personas, que anteriormente no tenían reconocido en sus leyes básicas o fundamentales.

La seguridad como derecho subjetivo viene reconocido en el artículo 17.1 de la $\mathrm{CE}^{37}$; el orden público se menciona como único motivo para que la Autoridad pueda prohibir y limitar el derecho de reunión y manifestación, por razones fundadas de su alteración, con peligro para personas y bienes, según el artículo 21.2 y en el artículo 16.1 como límite a la libertad ideológica y de culto, se señala el orden público protegido por la ley.

Garantizar la seguridad ciudadana y proteger el libre ejercicio de los derechos y libertades, constituye la principal misión de las Fuerzas y Cuerpos de Seguridad, bajo la dependencia del Gobierno. El artículo 149.1.29. ${ }^{a}$ señala como competencia exclusiva del Estado, la seguridad pública, «sin perjuicio de la posibilidad de creación de policías por las Comunidades Autónomas en la forma que se establezca en los respectivos Estatutos en el marco de lo que disponga una ley orgánica».

Aunque parezca que las expresiones seguridad ciudadana y seguridad pública sean sinónimas y son utilizadas por la Constitución en el artículo 104 y 149 con el mismo sentido, se aprecian diferencias y matizaciones que es preciso resaltar. La Constitución abandona el concepto de orden público ${ }^{38}$ para referirse a la actividad o misión de la Policía, que denomina seguridad ciudadana y protección del ejercicio de los derechos y libertades de los ciudadanos; y al referirse a la seguridad pública, como competencia exclusiva del Estado, no utiliza el término de seguridad ciudadana, sino de forma indirecta, al permitir que ésta pueda ser asumida por las Policías autonómicas, pero no se transfiere la competencia de la seguridad ciudadana, sino de la misión, función o actividad y, por ende, de la creación de cuerpos de

${ }^{36}$ AVILÉS FARRÉ, Juan. Por un concepto más amplio de seguridad, Monografía $\mathrm{n}$ 55 del CESEDEN. Director: Ignacio Cosidó Gutiérrez; Coordinador, José M. Amor Huidobro; Revisión de la Defensa Nacional; Secretaría General Técnica del Ministerio de Defensa, Madrid, 2002.

${ }^{37}$ Artículo 17.1 de la CE «Toda persona tiene derecho a la libertad y a la seguridad».

${ }^{38}$ IZU BELLOSO, Miguel J. en Los conceptos de orden...op. c, pág. 12, afirma lo contrario. 
policía autonómicos. Parece dar a entender el constituyente que entiende la seguridad pública como un concepto más amplio que la misión propia de la policía o de la seguridad ciudadana y que podría abarcar otras funciones, tales como las relacionadas con catástrofes, desgracias, desastres naturales... etc. y conocidas genéricamente como medidas o funciones ${ }^{39}$ de protección civil, y cuya competencia, en su conjunto, tiene atribuida, como exclusiva, el Estado.

Es en este punto donde radica la diferencia entre orden público, como atributo de poder establecido para su mantenimiento y al margen de las libertades y prohibición de su ejercicio para los ciudadanos, y la seguridad ciudadana, como derecho a proteger por el poder público para que los ciudadanos puedan ejercer y ejercitar sus derechos y libertades, sólo limitadas por otros derechos y libertades constitucionalmente también protegidas y que es preciso ponderar.

El concepto tradicional de orden público guarda relación con una situación impuesta y exigida institucionalmente de forma genérica, o abstracta en beneficio de las clases o élites dominantes. El concepto de seguridad es reconocido en las constituciones modernas como un derecho fundamental de las personas. El orden público viene impuesto por los poderes públicos; la seguridad es un derecho individual y colectivo. La seguridad ciudadana hace referencia a la tranquilidad de las personas y ausencia de perturbaciones en el desarrollo normal y vital de su quehacer diario, cuya protección y planificación corresponde a las Autoridades, de tal forma que se haga realidad el derecho subjetivo de la seguridad.

Tradicionalmente el orden público se ha venido clasificando en material y formal, amplio o restringido; incluso se ha clasificado en orden público jurídico, económico, familiar, medioambiental... etc.

Acedo Penco clasifica el orden público en amplio, antiguo o vulgar, que hace referencia a los disturbios, alborotos o sucesos que trascienden del ámbito particular y alteran la normalidad y paz ciudadana; y en sentido restringido, técnico o nuevo y que se manifiesta como límite de la voluntad de los particulares y cláusula de cierre del ordenamiento jurídico a interpretar por los jueces ${ }^{40}$.

${ }^{39}$ Así lo entiende el Tribunal Constitucional en STC de 18 de diciembre de 1984, que refiriéndose a la seguridad pública del artículo 149 de la CE, la define como «el conjunto de acciones dirigidas a evitar, reducir o corregir los daños causados a personas y bienes por toda clase de medios de agresión y por los elementos naturales o extraordinarios en tiempos de paz cuando la amplitud y gravedad de sus efectos les hace alcanzar el carácter de calamidad pública».

${ }^{40}$ ACEDO PENCO, Ángel. El orden público actual..., op. cit., págs. 427-428. 
Izu Belloso ${ }^{41}$, clasifica el orden público en material o en sentido restringido, que consistiría en un orden exterior o tranquilidad con ausencia de agresiones, motines o revueltas y orden público formal o en sentido amplio, como límite a la voluntad de los particulares y cláusula de cierre del ordenamiento ${ }^{42}$.

Denominar orden público a las razones, ya sean de tipo legal imperativo, de valores o principios, de buenas costumbres, éticas o morales, por las que no es de aplicación una norma extranjera, dentro del Derecho Internacional privado, y utilizar la misma locución para expresar las razones por las que una unidad militar, semi-militar o policial resuelve/disuelve un motín, un altercado, una reunión o una manifestación, resulta inadecuado y al término debe concedérsele distintas acepciones o, incluso, ser objeto de revisión.

La Seguridad nacional, abarca la seguridad interior y la seguridad exterior. La seguridad interior comprende, fundamentalmente, la defensa del orden constitucional y la seguridad pública. La defensa del orden constitucional la tienen atribuida las Fuerzas Armadas, ${ }^{43} \mathrm{como}$ sujeto activo secundario, bajo los auspicios y mando del Ministerio de Defensa; y la seguridad pública es competencia del Ministerio del Interior, cuyos sujetos activos secundarios, respecto de la seguridad ciudadana, son las Fuerzas y Cuerpos de Seguridad, y los servicios de protección civil. El sujeto activo primario, tanto de la defensa del orden constitucional como de la seguridad pública, y la competencia directa la ostenta el Gobierno de la nación.

La seguridad pública es definida por Recasens como «la competencia de las instancias públicas cuyo objetivo consiste en establecer, mantener y eventualmente restaurar las condiciones de un estado de convivencia que permita el efectivo ejercicio de derechos y libertades de todos sus habitantes» ${ }^{44}$.

${ }^{41}$ IZU BELLOSO, Miguel José. Los conceptos de orden..., op. cit., pág. 2.

${ }^{42}$ Artículos 6 y 1.255 del Código Civil, así como el artículo 12 y el 20.

${ }^{43}$ Artículo 8.1 de la CE.

${ }^{44}$ "...Como estado de convivencia, constituye una situación prolongada en el tiempo, en que los ciudadanos de una determinada sociedad, regida por unas mismas instancias públicas, actúan con la expectativa razonable de que las condiciones de convivencia no se van a ver alteradas o que, si tal cosa llega a suceder, las instituciones acudirán en su ayuda. Se trata de un concepto integral, que incorpora diversos ámbitos de la seguridad como pueden ser la seguridad ciudadana, la protección civil, la seguridad vial, la cobertura del auxilio en casos de catástrofe, aspectos sanitarios epidemiológicos,...» RECASENS I BRUNET, Amadeu. La seguridad y sus politicas. Editorial Atelier, Barcelona, 2007, pág. 133. 
Hemos realizado una exposición y análisis, no pacífico, de los conceptos de Orden público, Seguridad pública y Seguridad ciudadana, en España. Si ampliamos el análisis a otros países con el mismo idioma, las diferencias de usos y conceptos son todavía mayores. En Iberoamérica utilizan los términos de seguridad nacional, seguridad pública, seguridad ciudadana u orden público de muy distinta forma según el país de referencia ${ }^{45}$.

En la actualidad no existe ninguna ley en vigor bajo el título de ley de orden público en España. La Constitución de 1978 distingue entre orden público ${ }^{46}$, seguridad ciudadana ${ }^{47}$ y seguridad pública ${ }^{48}$, como ya hemos expuesto, al margen de disquisiciones académicas que por lo que parece no han logrado unificar y clarificar la definición y las clasificaciones del orden público.

La institución seguridad ciudadana se conforma como un bien constitucionalmente protegido, cuyos titulares se concretan, por una parte, en cuanto al sujeto activo, en el Gobierno como sujeto activo primario, y por otra, en las Fuerzas y Cuerpos de seguridad como sujeto activo secundario; los ciudadanos, en su calidad de participantes en la vida de la comunidad, constituyen el sujeto pasivo.

El objeto o contenido de la seguridad ciudadana consistirá en las medidas de prevención, protección, garantía y reparación que se tengan que adoptar para que los ciudadanos puedan intervenir libremente y con garantías en los distintos niveles y formas participativas que presenta la vida en comunidad. La seguridad ciudadana adopta constitucionalmente una función prestacional a cargo del Gobierno y de las Fuerzas y Cuerpos de seguridad bajo la dependencia de aquél, los cuales, a su vez, se constituyen en garantía institucional de la seguridad ciudadana y del libre ejercicio de los derechos y libertades.

Desde esta perspectiva, la seguridad interna, como garantía del libre ejercicio de los derechos de los ciudadanos y de las libertades públicas, es una responsabilidad que corresponde primordialmente al Estado; garantizarla es, por tanto una función esencial del mismo, y se basa en el derecho soberano de cada Estado para identificar y defi-

${ }^{45}$ En parte, motivado por los repercusiones que tuvo la doctrina de la Seguridad Nacional.

${ }^{46}$ Artículo 16.1 y 21.2 de la CE, como limitación a la libertad religiosa y prohibición de manifestaciones.

${ }^{47}$ Artículo 104.1 de la CE «Las Fuerzas y Cuerpos de Seguridad, bajo el gobierno de la nación, tendrán como misión proteger el libre ejercicio de los derechos y libertades y garantizar la seguridad ciudadana.

${ }^{48}$ Artículo 149.1.29. ${ }^{a}$ de la CE señala como competencia exclusiva del Estado la Seguridad pública. 
nir sus propias prioridades de inseguridad y definir las estrategias para neutralizarlas ${ }^{49}$.

Con la Revolución francesa y la Declaración de los Derechos del Hombre y del Ciudadano se definen como universales e inherentes a las naturaleza humana los derechos personales y colectivos, con cuatro principios fundamentales: la libertad, la propiedad, la seguridad y la resistencia a la opresión, y «siendo necesaria una fuerza pública para garantizar los derechos del hombre y del ciudadano, se constituirá esta fuerza en beneficio de la comunidad y no para el provecho particular de las personas a las que ha sido confiada ${ }^{50}$.

\section{B. La Ley Orgánica de Protección de la Seguridad Ciudadana de 1992}

Algunos autores incluyen dentro de las leyes de orden público, la Ley Orgánica 1/1992 de 21 de febrero, de Protección de la Seguridad Ciudadana, promulgada al amparo del artículo 149.1.29. ${ }^{\mathrm{a}}$ y 104.1 de la Constitución en cuanto a la competencia estatal, afectación de derechos fundamentales, y la atribución a las Fuerzas y Cuerpos de Seguridad, bajo la dependencia del Gobierno, de proteger el libre ejercicio de los derechos y libertades y de garantizar la seguridad ciudadana.

Dicha ley fue conocida como la "Ley Corcuera» ${ }^{51}$ o de la patada en la puerta. Este apelativo le fue adjudicado por intentar definir o regular el delito flagrante, identificando los términos de urgencia, conocimiento fundado o constancia de que se está cometiendo, o se ha cometido un delito, sin los requisitos expuestos por la doctrina y la jurisprudencia que exigen no conjeturas o sospechas sino certeza de tales hechos para apreciar la flagrancia y poder justificar tales actuaciones $^{52}$.

${ }^{49}$ FUENTE COBO, Ignacio. «Intereses que afectan a la vida, el bienestar y seguridad de los españoles»; Monografías del CESEDEN Núm. 115, Coordinador C. CORTEJOSO HERNÁNDEZ. Evolución del concepto de Interés Nacional. Madrid, 2010, pág. 96.

${ }^{50}$ Artículo XII de la Declaración de los Derechos del Hombre y del Ciudadano, aprobada por la Asamblea Nacional Constituyente francesa de 26 de agosto de 1789.

${ }^{51}$ El Proyecto de Ley fue presentado en el Parlamento por el Ministro del Interior don José Luis Corcuera.

${ }^{52}$ La Sentencia del Tribunal Constitucional STC 341/1993, de 18 de noviembre declaró anticonstitucional el artículo 21.2 de la Ley Orgánica de Protección de la Seguridad Ciudadana, con el siguiente tenor literal: «A los efectos de lo dispuesto en el párrafo anterior, será causa legítima para la entrada y registro en domicilio por delito flagrante el conocimiento fundado por parte de las Fuerzas y Cuerpos de Seguridad que les lleve a la constancia de que se está cometiendo o se acaba de cometer alguno de os 
En la exposición de motivos se afirmaba que en el equilibrio entre libertad y seguridad, mantenido por las Cortes Generales, se habían aprobado las Leyes Orgánicas de 1 de junio de 1981, de los estados de alarma, excepción y sitio; la de 1 de julio de 1985, sobre derechos y libertades de los extranjeros en España y la Ley de 13 de marzo de 1986 de Fuerzas y Cuerpos de Seguridad; leyes especiales, como la de 15 de julio de 1983, reguladora del derecho de reunión; la de 21 de enero de 1985 sobre protección civil, o la 25 de julio de 1989, de Bases sobre Tráfico, circulación de vehículos de motor y seguridad vial, incluyéndose, asimismo, medidas de prevención de la violencia en espectáculos deportivos mediante la Ley del Deporte, 10/1990, de 15 de octubre.

Derogada ya la última ley de orden público, se consideraba necesario regular y desarrollar las facultades o potestades de las autoridades actualizadas y adecuadas a la Constitución, y con la finalidad de proteger la seguridad ciudadana, en materia de fabricación, comercio, tenencia y uso de armas y explosivos, concentraciones públicas en espectáculos; documentación personal de nacionales y extranjeros en España; así como regular ciertas actividades de especial interés y responsabilidad para las Fuerzas y Cuerpos de Seguridad.

En el capítulo IV, y último, se establecía un régimen sancionador, tipificando las infracciones a la seguridad ciudadana en muy graves, graves y leves y las respectivas sanciones, así como las Autoridades competentes para su imposición, previo el correspondiente expediente sancionador.

La tenencia de sustancias estupefacientes o su consumo en la vía público, la negativa a identificarse cuando se es requerido por los Agentes de la Autoridad; la no obtención del Documento Nacional de Identidad a partir de los catorce años, fueron, entre otras, materias reguladas que no lo estaban anteriormente o lo estaban por normas de inferior rango y no adecuado a la Constitución.

La cobertura legal para solicitar la documentación personal a efectos de identificación, por parte de los funcionarios de Policía, queda establecida ante la existencia de indicios relacionados con una infracción penal o administrativa. El traslado a dependencias policiales con dicho fin planteó problemas de legalidad al establecerse una nueva figura restrictiva del derecho a la libertad o de deambular no contemplada anteriormente: la retención. Término intermedio entre la situación

delitos que, en materia de drogas tóxicas, estupefacientes o sustancias psicotrópicas, castiga el Código Penal, siempre que la urgente intervención de los agentes sea necesaria para impedir la consumación del delito, la huida del delincuente o la desaparición de los efectos o instrumentos del delito». 
de libertad y detención que no ha sido suficiente y adecuadamente desarrollado y cuestionándose, entonces, su constitucionalidad.

La Ley Orgánica de Protección de la Seguridad Ciudadana de 1992, mal estructurada y manifiestamente mejorable técnicamente, no reúne los elementos propios, al menos desde el punto de vista formal, de las anteriores leyes de Orden Público; más bien constituye un «cajón de sastre», bien para dar cobertura legal a ciertas actuaciones de la Administración o de sus funcionarios que ya se venían realizando de forma alegal $^{53}$, bien para compeler a ciertas actuaciones individuales, como la obtención de Documento Nacional de Identidad, obligaciones derivadas del ejercicio de una actividad o de establecimientos con repercusión en la seguridad ciudadana, como libros-registro en pensiones, hospedajes, venta de objetos y piedras preciosas, compra y venta de objetos de segunda mano, desguace de vehículos,... etc., o bien para sancionar actividades o conductas para las cuales no existía base legal para, pese a considerarlas reprobables, debido, principalmente, al vacío legal producido por la derogación, expresa o tácita, de leyes administrativas del régimen político anterior contrarias a la Constitución y que, a su vez, carecían de tipicidad y sanción penal.

\section{C. La Ley Orgánica 4/2.015, de 30 de marzo, de Protección de la Seguridad Ciudadana}

Los Grupos parlamentarios de la oposición negaron la necesidad de una nueva ley por estar ya regulada la materia, por falta de motivos materiales por cuanto los índices delincuenciales anuales descienden anualmente y alegaron que la única pretensión del Gobierno era acallar las críticas de la oposición y de ahí el apelativo de «ley mordaza»; que ha sido objeto de recurso ante el Tribunal Constitucional.

Entre los temas que produjeron un mayor rechazo y comentarios en los medios de comunicación fueron la prohibición de manifestaciones en las inmediaciones de los Parlamentos, la regulación de la retención y cacheos corporales con una mayor concesión de facultades a las fuerzas policiales, la posibilidad de rechazo en frontera para los extranjeros y el incremento de las infracciones y del importe de las sanciones.

${ }^{53}$ Determinadas actividades y establecimientos quedaron sometidas a registros documentales, como el hospedaje, el comercio o reparación de objetos usados, el alquiler o desguace de vehículos, la compraventa de joyas y metales preciosos... (artículo 12 de la LOPSC). 
En la exposición de motivos de la Ley Orgánica se justifica la necesidad de la nueva normativa en las carencias de la ley anterior, el cambio social producido, los nuevos riesgos para la seguridad, nuevas demandas sociales y la incorporación de la jurisprudencia constitucional. Considera la seguridad como un instrumento para la libertad y no como un fin en sí mismo, pese a lo cual justifica la limitación de las libertades ciudadanas por razones de seguridad; no obstante exige los principios de legalidad y proporcionalidad, con sus tres elementos: juicio de idoneidad, juicio de necesidad y juicio de proporcionalidad estricta.

$\mathrm{Al}$ respecto, cabe afirmar que el artículo 17.1 de la Constitución afirma literalmente que «toda persona tiene derecho a la libertad y a la seguridad». No afirma que la seguridad es un medio para la libertad o al revés, sino que equipara el rango de ambos derechos. Pero el razonamiento de la exposición de motivos es totalmente contradictorio por cuanto afirma que la seguridad no es un fin en sí mismo, sino que es un medio, pero para lograrla se justifica la limitación de libertades ciudadanas. Tal razonamiento parece extraído del antiguo concepto de orden público como atributo de la soberanía o poder ejecutivo donde la seguridad constituía un medio para realizar su proyecto vital las élites dominantes. Los límites de los derechos fundamentales deben fijarse no en base a ser primarios o secundarios, mediáticos o finalistas, sino ante la concurrencia de otros derechos, constitucionalmente también protegidos, y que exigen una ponderación de los intereses en presencia o en conflicto.

La Ley Orgánica de Protección de la Seguridad Ciudadana, de 30 de marzo de 2015, coincidió en su aprobación con la Ley Orgánica 1/2015, de reforma del Código Penal, complementándose o duplicándose, a veces, en lo relativo a la seguridad ciudadana ${ }^{54}$.

La nueva ley, de forma semejante a la anterior, regula la documentación e identificación de personas; el control administrativo de armas, explosivos, cartuchería y artículos pirotécnicos; regula las medidas de seguridad a adoptar en determinados establecimiento; registro documental para determinas actividades; regula la protección de personas y bienes y del libre ejercicio de derechos y libertades; pretende garantizar el normal funcionamiento de las instituciones y la pacífica utilización de bienes públicos y demaniales, así como garantizar la normal prestación de servicios básicos; regula la intervención

${ }^{54}$ Se suprimen las Faltas; Se modifica el delito de Atentado; se elimina del Código Penal la desobediencia leve a los Agentes de la Autoridad; se regula en ambos textos normativos la resistencia y desobediencia y la falta de respeto y consideración debida a los miembros de las Fuerzas y Cuerpos de Seguridad... etc. 
administrativa en espectáculos públicos y actividades recreativas y la prevención de la comisión de delitos e infracciones administrativas y su sanción correspondiente.

Como principios rectores, además de incluir los principios básicos de actuación del artículo 5 de la Ley Orgánica de Fuerzas y Cuerpos de Seguridad 2/86, de 13 de marzo, se señala que las autoridades y funcionarios deberán regirse por los principios de legalidad, igualdad de trato y no discriminación, oportunidad, proporcionalidad, eficacia, eficiencia y responsabilidad.

Todas las actuaciones reguladas por la Ley Orgánica se someterán al control administrativo y jurisdiccional y las instrucciones del cap. III y V se interpretarán del modo más favorable a la plena efectividad de los derechos fundamentales, y especialmente, derecho de reunión, manifestación, expresión, información, libertad sindical y derecho de huelga.

Todo el interés despertado con el anuncio de la nueva Ley Orgánica de Protección de la Seguridad Ciudadana, motivado especialmente por las críticas de la oposición política, se convirtió en frustración ante la realidad y en contra de la expectativa de los profesionales de la seguridad pública que habían intuido una mayor profundidad legislativa y una ampliación de sus capacidades en defensa de la seguridad colectiva.

La posibilidad de entrada y registro en domicilios, con motivo de calamidad, desastre, desgracia o riesgo inminente para personas y bienes, no sufre alteración; ya se trate de domicilios particulares o edificios ocupados por organismos oficiales. ${ }^{55}$ Siendo obligatorio la instrucción del correspondiente atestado o acta para su remisión inmediata a la Autoridad judicial.

Señala la Ley Orgánica, que en cumplimientos de sus funciones de indagación y prevención delictiva, así como para la sanción de infracciones penales y administrativas, los Agentes de las FF. CC. S podrán requerir la identificación de personas en los siguientes supuestos:

a. Cuando existan indicios de que han podido participar en la comisión de una infracción.

${ }^{55}$ Así lo expresaba el proyecto de ley del Congreso de los Diputados, que afirmaba «No será preciso consentimiento de la autoridad o funcionario que tuviese a su cargo un edificio ocupado por organismo oficial en los mismos supuestos anteriores (riesgos inminentes, y que en la redacción definitiva de la ley, posiblemente por error $\mathrm{u}$ omisión, no se incluye). 
b. Cuando, en atención a las circunstancias concurrentes, se considere razonablemente necesario que acrediten su identidad para prevenir la comisión de un delito (artículo 16).

Se incluye como identificación la comprobación del rostro que no sea total o parcialmente visible (artículo 16.1). Esta es la única novedad al respecto.

También, ante la posibilidad e indicios de hallar instrumentos, efectos u otros objetos relevantes para las funciones de indagación y prevención, se podrá practicarse el registro corporal externo y salvo riesgo inminente y grave para los agentes, se realizará por un agente del mismo sexo.

Si se exigiera dejar a la vista partes del cuerpo humano normalmente cubiertas por ropa, se efectuará en un lugar reservado y fuera de la vista de terceros. En este supuesto deberá constar por escrito, mediante Diligencia, señalando las causas y la identidad del agente que adopta tal medida. Su puede adoptar dicha medida en contra de la voluntad del afectado, adoptando las medidas de compulsión indispensables (artículo 20). Es este el primer intento de regulación administrativa de los registros corporales externos y que, en el ámbito penal, ha sido objeto de numerosa literatura jurídica.

Se viene considerando la función de identificación policial como la limitación o prohibición del derecho a deambular. Anteriormente, cualquier otra limitación de la libertad se incluía en la figura de la detención, con las motivaciones, causas y derechos establecidos en la Ley de Enjuiciamiento criminal y, fundamentalmente, en su artículo 520. Con la Ley Orgánica de Protección de la Seguridad Ciudadana de 1992 se instauró la figura de la retención ${ }^{56}$. Situación intermedia entre la privación del derecho a deambular y la situación de detención. En la ley del 92, la retención, o la privación del derecho a deambular durante el tiempo utilizado para el traslado a dependencias policiales y el tiempo necesario para conseguir la identificación, no tenían señalado plazo máximo. El mínimo es el imprescindible y necesario para llevar a la práctica dicha Diligencia, a partir del cual la limitación de libertad podría ser constitutiva de la infracción penal de detención ilegal. El tiempo máximo en la situación de identificación, y según la exposición de motivos de la nueva ley, por indicación del informe del Consejo General del Poder Judicial, se establece en el término de Seis horas. A partir de las cuales el retenido deberá pasar a la situación de libertad o de detención, según las circunstancias concurrentes.

${ }^{56}$ La locución «retención» no figura ni en la Ley de 1992 ni en la ley de 2015. La utilizamos como figura intermedia entre la identificación «in situ» y la detención. 
Procederá el traslado a dependencias policiales cuando no sea posible la identificación por cualquier medio o si la persona se negase a identificarse; y con la finalidad de impedir la comisión de un delito o al objeto de sancionar una infracción. Los derechos del identificado y del retenido consisten en la información inmediata y comprensible de las medidas adoptadas, excluyéndose de forma explícita, la aplicación de los derechos y formalidades establecidos para la detención (art. 19.1).

Señala la LOPSC de 2.015, al igual que la de 1992, que en las dependencias policiales existirá un Libro-Registro para asientos relacionados con la SC, en el que constarán las Diligencias de identificación practicadas, motivos y circunstancias y duración de las mismas y de su contenido sólo se podrá informar a la Autoridad judicial y al Ministerio Fiscal $^{57}$. La remisión mensual al Ministerio Fiscal del extracto de las Diligencias de identificación ya estaba prescrita en la ley del 92. Los asientos se cancelarán de oficio a los 3 años. Y a las personas desplazadas a Comisaría se les deberá expedir a su salida un volante acreditativo del tiempo de permanencia en ella, la causa y la identidad de los agentes actuantes (art. 16.4); exigencia que impone la nueva normativa.

También los Agentes de las FF. CC. S podrán limitar o restringir la circulación o permanencia en vías o lugares públicos y establecer zonas de seguridad en supuestos de alteración de la SC o existan indicios de que puedan producirse. Será por el tiempo imprescindible para el mantenimiento y restablecimiento de la SC. Igualmente podrán ocupar preventivamente los efectos o instrumentos susceptibles de ser utilizados para acciones ilegales, prevención de delitos de especial gravedad y que provoquen alarma social, así como para su descubrimiento y recogida de efectos o pruebas, se podrán establecer controles en la vía, lugares o establecimientos públicos, siempre que resulte indispensable proceder a la identificación de personas, registro de vehículos o el control superficial de efectos personales. Se podrá proceder a la ocupación temporal de instrumentos, objetos o medios de agresión, incluso armas con licencia y guía, si se considera necesario para prevenir la comisión de cualquier delito o exista peligro para la seguridad de personas o bienes; tal y como se reflejaba, igualmente en la Ley Orgánica de Protección de la Seguridad Ciudadana de 1992.

La ley permite la grabación de personas, lugares y objetos mediante cámaras de video-vigilancia, fijas o móviles, legalmente autorizadas, por parte de las Fuerzas y Cuerpos de Seguridad y de acuerdo

${ }^{57}$ Dicho Libro-Registro ya existe en todas las dependencias policiales; ignorándose si se confeccionará uno nuevo o continuarán en vigor los existentes. 
con la legislación vigente en la materia ${ }^{58}$ y que ya fue desarrollada en el año 1997, por cuanto en 1992 los desarrollos técnicos hacían muy difícil o imposible las mencionadas grabaciones.

La Autoridad ${ }^{59}$ adoptará las medidas necesarias para proteger la celebración de reuniones y manifestaciones, impidiendo que se perturbe la seguridad ciudadana.

Se podrá acordar la disolución de reuniones en los supuestos del artículo 5 de la LO 9/1983 de 15 de julio, reguladora del derecho de reunión ${ }^{60}$. También se podrán disolver las concentraciones de vehículos en la vía pública y retirar cualquier otra clase de obstáculos que impidieren o pusieran en peligro o dificultaren la circulación. La disolución de las reuniones constituirá el último recurso. Antes de adoptar tales medidas acordadas por la Autoridad, las FF.CC. S deberán avisar de dichas medidas, pudiendo hacerlo de forma verbal si la urgencia lo hiciere imprescindible; o, incluso, no hacerlo si fueren atacadas o agredidas con armas o artefactos explosivos.

Como actividades relevantes para la seguridad ciudadana la nueva ley señala: El hospedaje, transporte de personas, acceso comercial a servicios telefónicos o telemáticos de uso público mediante establecimientos abiertos al público, comercio o reparación de objetos usados, alquiler o desguace de vehículos de motor, compraventa de joyas y metales, ya sean preciosos o no, objetos u obras de arte, cerrajería de seguridad, centros gestores de residuos metálicos, establecimientos de comercio al por mayor de chatarra o productos de desecho, o de venta de productos químicos peligrosos a particulares. Sus titulares quedarán sujetas a las obligaciones de registro documental e información en los términos que establezcan las disposiciones aplicables (art. 25.1). Y los titulares de embarcaciones de alta velocidad, así como los de aeronaves

${ }^{58}$ Ley Orgánica 4/1997, de 4 de agosto por la que ser regula la utilización de video-cámaras, fijas o móviles, por las Fuerzas y Cuerpos de Seguridad en lugares públicos.

${ }^{59}$ Según la Ley y a estos efectos son Autoridad: El Ministro del Interior, El Secretario de Estado de Seguridad; los Delegados del Gobierno y responsables de las Comunidades Autónomas en materia de Seguridad Ciudadana, una vez transferida.

${ }^{60} \mathrm{El}$ artículo 5. ${ }^{\circ}$ de la LO 9/1983, señala como causas de suspensión o disolución de las manifestaciones, por la autoridad gubernativa, cuando se consideren ilícitas conforme con las leyes penales; cuando se produzcan alteraciones del orden público, con peligro para personas o bienes; cuando se hiciere uso de uniformes paramilitares por los asistentes; y cuando fueren organizadas por miembros de las Fuerzas Armadas o de la Guardia Civil, infringiendo las limitaciones impuestas por el artículo 13 de la LO 9/2011, de 27 de julio y del artículo 8 de la LO 11/2007, de 22 de octubre reguladora de los derechos y deberes de los miembros de la Guardia Civil. 
ligeras que estarán obligados a realizar las actuaciones de registro documental e información previstas en la normativa vigente (art. 25.2).

Es competencia del Gobierno la regulación de los requisitos y condiciones de fabricación, reparación, circulación, almacenamiento, comercio, adquisición, enajenación, tenencia y utilización de armas, sus imitaciones, réplicas y piezas fundamentales, de los explosivos, cartuchería y artículos pirotécnicos; así como la adopción de las medidas de control necesarias para el cumplimiento de dichos requisitos y condiciones.

Y es competencia del Ministerio del Interior, ejercida a través de la Dirección General de la Guardia Civil, la intervención de armas, explosivos, cartuchería y artículos pirotécnicos, cuyos servicios están habilitados para realizar en cualquier momento las inspecciones y comprobaciones que sean necesarias en los espacios que estén destinados a su fabricación, depósito, comercialización o utilización (arts. 28.1 y 2).

Los responsables de las infracciones serán directamente los autores del hecho y posibilidad de responsabilidad para promotores-organizadores o que presidan, publiquen o dirijan reuniones o manifestaciones.

Están exentos de responsabilidad los menores de 14 años. Cuando el responsable sea menor de 18 años, no emancipado, o persona con la capacidad modificada judicialmente responderán, solidariamente con él, de los daños y perjuicios ocasionados, sus padres, tutores, curadores, acogedores o guardadores legales o de hecho.

$\mathrm{Al}$ infractor se le exige la reposición a su estado originario de la situación alterada.

El precepto especial se aplicará sobre el general; el más amplio o complejo absorberá el que sancione las infracciones consumidas en aquél; y el más grave excluirá los que sancionen el hecho con una sanción menor.

El principio de proporcionalidad en la imposición de sanciones se aplicará en las multas por las infracciones muy graves y graves que se dividirán en tres tramos iguales: mínimo, medio y máximo ${ }^{61}$.

${ }^{61}$ La comisión de una infracción determinará la imposición de la multa correspondiente en grado mínimo, y se sancionará en grado medio cuando concurra una de las siguientes circunstancias:

a) La reincidencia, (comisión en el término de dos años de más de una infracción de la misma naturaleza, por resolución firme en vía administrativa).

b) La realización de los hechos interviniendo violencia, amenaza o intimidación.

c) La utilización de cualquier tipo de prenda u objeto que cubra el rostro, impidiendo o dificultando la identificación.

d) Utilización de menores de edad, discapacitados o en situación de vulnerabilidad. 
La entidad del riesgo producido; la cuantía del perjuicio causado; la trascendencia del perjuicio para la prevención, mantenimiento y restablecimiento de la SC; la alteración en el funcionamiento de los servicios públicos o en el abastecimiento a la población; el grado de culpabilidad; el beneficio reportado por comisión de la infracción y la capacidad económica del infractor, se tendrán en cuenta para la aplicación de los grados.

Las infracciones leves prescribirán a los 6 meses; las graves, al año; y las muy graves a los dos años. Los plazos se computarán desde el día en que se haya cometido la infracción y la prescripción se interrumpirá por cualquier actuación administrativa de la que tenga conocimiento formal el interesado dirigido a la sanción de la infracción. El cómputo del plazo de prescripción se reanudará si el procedimiento estuviera paralizado más de un mes por causa no imputable al presunto responsable. Se interrumpirá igualmente la prescripción como consecuencia de la apertura de un procedimiento judicial penal, hasta que la autoridad judicial comunique al órgano administrativo su finalización en los términos del apartado 2 del artículo 45 (art. 38).

Las infracciones muy graves se sancionarán con multa de 30.001 a 600.000 euros; las graves, con multa de 601 a 30.000 euros, y las leves, con multa de 100 a 600 euros $^{62}$.

La sanción de multa podrá llevar aparejadas sanciones accesorias, atendiendo a la naturaleza de los hechos constitutivos de la infracción:

a. La retirada de las armas y de las licencias o permisos correspondientes a las mismas.

b. El comiso de los bienes, medios o instrumentos con los que se haya preparado o ejecutado la infracción y, en su caso, de los efectos procedentes de ésta*.

c. La suspensión temporal de las licencias, autorizaciones o permisos desde seis meses y un día a dos años por infracciones muy graves y hasta seis meses para las infracciones graves, en el ámbito de las materias reguladas en el capítulo IV de esta Ley.

62 a) Para las infracciones muy graves, el grado mínimo comprenderá la multa de 30.001 a 220.000 euros; el grado medio, de 220.001 a 410.000 euros, y el grado máximo, de 410.001 a 600.000 euros.

b) Para las infracciones graves, el grado mínimo comprenderá la multa de 601 a 10.400; el grado medio, de 10.401 a 20.200 euros, y el grado máximo, de 20.201 a 30.000 euros (art. 39). 
d. La clausura de las fábricas, locales o establecimientos, desde seis meses y un día a dos años por infracciones muy graves y hasta seis meses por infracciones graves, en el ámbito de las materias reguladas en el capítulo IV de esta Ley.

Las sanciones impuestas por infracciones muy graves prescribirán a los tres años; las impuestas por infracciones graves, a los dos años; y las impuestas por infracciones leves, al año (art. 40).

Se efectuará pronunciamiento expreso cuando las conductas sancionadas hayan ocasionado daños o perjuicios a la administración pública, y la resolución determinará:

a. La exigencia al infractor de la reposición a su estado originario de la situación alterada por la infracción.

b. Cuando ello no fuera posible, la indemnización por los daños y perjuicios causados, si éstos hubiesen quedado determinados durante el procedimiento. Si el importe de los daños y perjuicios no hubiese quedado establecido, se determinará en un procedimiento complementario, susceptible de terminación convencional, cuya resolución pondrá fin a la vía administrativa.

La responsabilidad civil derivada de una infracción será siempre solidaria entre todos los causantes del daño (art. 42).

En el Ministerio del Interior se crea un Registro Central de Infracciones contra la Seguridad Ciudadana, en el que constarán los siguientes asientos: a) Datos personales del infractor. b) Infracción cometida. c) Sanción o sanciones firmes en vía administrativa impuestas, con indicación de su alcance temporal, cuando proceda. d) Lugar y fecha de la comisión de la infracción. e) Órgano que haya impuesto la sanción ${ }^{63}$.

Los asientos se cancelarán de oficio transcurridos tres años, cuando se trate de infracciones muy graves, dos años, en el caso de infracciones graves y uno en el de infracciones leves, a contar desde la firmeza de la sanción. Reglamentariamente se regulará la organización y funcionamiento del Registro Central (art. 43).

El ejercicio de la potestad sancionadora se regirá por el título IX de la Ley 30/1992, de 26 de noviembre (art. 44) y, sometida, en su

${ }^{63}$ Información de la anotación al infractor: Podrán solicitar el acceso, cancelación o rectificación de sus datos de conformidad con lo establecido en la Ley Orgánica 15/1999, de 13 de diciembre, de Protección de Datos de Carácter Personal.

(C) UNED. Revista de Derecho UNED, núm. 17, 2015 
caso, a la Ley 29/1998, de 13 de julio, reguladora de la Jurisdicción Contencioso-administrativa.

Como excepción al apartado anterior se establece el procedimiento abreviado, para las infracciones graves y leves. Una vez notificado el acuerdo de incoación del procedimiento, el interesado dispondrá de un plazo de quince días para realizar el pago voluntario con reducción de la sanción de multa, o para formular las alegaciones y proponer o aportar las pruebas que estime oportunas. De efectuar el pago de la multa, se seguirá dicho procedimiento, con reducción del 50\% del importe de la sanción de multa y la renuncia a formular alegaciones. En este supuesto el procedimiento se dará por finalizado, sin necesidad de resolución expresa, y siendo recurrible la sanción únicamente en vía contenciosa (art. 54).

Cuando las conductas pudieran ser constitutivas de delito, el órgano administrativo pasará el tanto de culpa a la autoridad judicial o al Ministerio Fiscal y se abstendrá de seguir el procedimiento sancionador mientras la autoridad judicial no dicte sentencia firme o resolución que de otro modo ponga fin al procedimiento penal, o el Ministerio Fiscal no acuerde la improcedencia de iniciar o proseguir las actuaciones en vía penal, quedando hasta entonces interrumpido el plazo de prescripción. En todo caso, el órgano administrativo quedará vinculado por los hechos declarados probados en vía judicial.

En los procedimientos sancionadores que se instruyan, las denuncias, atestados o actas formulados por los agentes de la autoridad en ejercicio de sus funciones que hubiesen presenciado los hechos, previa ratificación en el caso de haber sido negados por los denunciados, constituirán base suficiente para adoptar la resolución que proceda, salvo prueba en contrario y sin perjuicio de que aquéllos deban aportar al expediente todos los elementos probatorios disponibles (art. 52).

En las infracciones de la LO 4/2015 se hace referencia a las instalaciones de servicios básicos (arts. 35.1 y 36.9) y en a Disposición Adicional sexta se señalan cuáles son estos servicios básicos para la comunidad $^{64}$.

La disposición final primera establece un régimen especial para Ceuta y Melilla, añadiendo una disposición adicional $\left(10 .^{\mathrm{a}}\right)$ a la Ley Orgánica 4/2000, de 11 de Enero, sobre derechos y libertades de los

${ }^{64}$ a) Centrales nucleares, petroquímicas, refinerías y depósitos de combustible.

b) Puertos, aeropuertos y demás infraestructuras de transporte.

c) Servicios de suministro y distribución de agua, gas y electricidad.

d) Infraestructuras de telecomunicaciones (disp., adic. 6. ${ }^{\mathrm{a}}$ ). 
extranjeros en España y su integración social, en las que se señala que los extranjeros que sean detectados en la línea fronteriza de la demarcación territorial de Ceuta o Melilla, mientras intentan superar los elementos de contención fronterizos, para cruzar irregularmente la frontera podrán ser rechazados a fin de impedir su entrada ilegal en España. En todo caso, el rechazo se realizará respetando la normativa internacional de derechos humanos y de protección internacional de la que España es parte. Las solicitudes de protección internacional se formalizarán en los lugares habilitados al efecto en los pasos fronterizos y se tramitarán conforme a lo establecido en la normativa en materia de protección internacional ${ }^{65}$.

Como infracciones muy graves, en la nueva ley, se señalan cuatro: La celebración de reuniones o manifestaciones no comunicadas o prohibidas en instalaciones de servicios básicos (art. 35.1); incumplir la normativa sobre armas y cartuchería causando perjuicios graves (art. 35.2). La celebración de espectáculos públicos o actividades recreativas quebrantando la prohibición o suspensión ordenada por la autoridad correspondiente por razones de seguridad pública (art. 35.3) y La proyección de haces de luz, mediante cualquier tipo de dispositivo, sobre los pilotos o conductores de medios de transporte que puedan deslumbrarles o distraer su atención y provocar accidentes (art. 35.4).

En la ley del 92 no se señalaban las infracciones muy graves, sino que se consideraban como tales algunas infracciones graves ante la concurrencia de circunstancias especiales. ${ }^{66}$ De igual manera, ante una tercera infracción leve, en el plazo de un año, también era considerada como falta grave. La nueva ley no modifica, en ningún caso, el carácter predeterminado de las infracciones.

En la descripción de las infracciones graves y leves no existe gran diferencia entre las dos leyes orgánicas, por lo que nos vamos limitar a señalar las que han sido incorporadas en la nueva ley o suprimidas de la primera.

No estaba prevista en la ley anterior como infracción grave, la perturbación grave de la seguridad ciudadana frente a las sedes de las asambleas legislativas ${ }^{67}$; como tampoco, la obstrucción para el cum-

${ }^{65}$ Esta disposición final 1. ${ }^{\text {a }}$, se encuentra en vigor desde el día siguiente a la publicación de la ley en el BOE (31-03-20015).

66 «... teniendo en cuenta la entidad del riesgo producido, ... transportes colectivos o regularidad en los abastecimientos, o se hubieren producido con violencia o amenaza colectiva». Artículo 24.

${ }^{67}$ «La perturbación grave de la seguridad ciudadana que se produzca con ocasión de reuniones o manifestaciones frente a las sedes del Congreso de los Diputados, el

(C) UNED. Revista de Derecho UNED, núm. 17, 2015 
plimiento de la ejecución de resoluciones judiciales o administrativas $^{68}$; o que impidan el normal funcionamiento de los equipos de emergencias. (Artículo 36.5).

La resistencia y desobediencia grave se encuentra tipificada en el artículo 556 del Código Penal y, como infracción grave, y en la nueva LOPSC, en el artículo 36.6, incluyendo, como tal, la negativa a identificarse.

La falta de respeto y consideración a la Autoridad se tipifica en el Código Penal ${ }^{69}$; y a sus agentes, se considera infracción leve en el artículo 37.4 de la nueva ley administrativa. La desobediencia leve genérica no tiene reconocimiento de infracción en ninguno de los dos textos sancionadores.

Se incluye como infracción grave la solicitud o aceptación de servicios sexuales retribuidos, en protección de menores y de riego para la seguridad vial; y para la persona que ofrezca dichos servicios se sanciona la desobediencia en el caso de, en tales supuestos, hacer caso omiso de las indicaciones de los agentes de la Autoridad (art. 36.11).

Como infracciones graves, se consideran el traslado de personas para facilitar el acceso a drogas y sustancias estupefacientes (art. 36.17) y la plantación o su cultivo en lugares visibles al público (art 36.18). Y finalmente, también se considera infracción grave el uso no autorizado de imágenes que puedan poner en peligro la seguridad personal o familiar de los integrantes de las FFCCS, de las instalaciones protegidas o el éxito de una operación, respetando, afirma el articulado, el derecho fundamental de la información.

Se incluyen como infracciones leves la proyección de haces de luz sobre los miembros de las FFCCS; incumplir las obligaciones de obtención de la documentación personal exigible, o la omisión negligente de la denuncia de sustracción o extravío, incluida la documentación de armas y explosivos; y la negligencia en la custodia de la documentación anterior, considerando como tal la tercera o posteriores pérdidas o extravíos en el plazo de un año.

Senado y las asambleas legislativas de las comunidades autónomas, aunque no estuvieran reunidas, cuando no constituya infracción penal» (art. 36.2).

68 «Los actos de obstrucción que pretendan impedir a cualquier autoridad, empleado público o corporación oficial el ejercicio legítimo de sus funciones, el cumplimiento o la ejecución de acuerdos o resoluciones administrativas o judiciales, siempre que se produzcan al margen de los procedimientos legalmente establecidos y no sean constitutivos de delito.» Artículo 36.4.

${ }^{69}$ Artículo 556.2. 
Al suprimirse del Código Penal como faltas, se incluyen como infracciones leves los daños o deslucimiento de bienes muebles o inmuebles de uso o servicio público; el escalamiento de edificios o monumentos sin autorización y riesgo cierto para personas o bienes; y el abandono de animales domésticos cuando pueda peligrar su vida o dejar sueltos o en condiciones de causar daños, animales feroces o dañinos.

El artículo 557 del reformado Código Penal se refiere a la alteración de la paz pública y sanciona a los que actuando en grupo, o amparándose en él, alteren la paz pública ejecutando actos de violencia sobre las personas o sobre las cosas, o amenazando a otros con llevarlos a cabo. La pena puede abarcar desde los seis meses hasta los tres años de prisión.

\section{CONCLUSIONES}

Hemos considerado el Orden Público como un concepto amplio y tres acepciones: La seguridad impuesta para el mantenimiento de las élites dominantes; las normas imperativas, buenas costumbres y principios esenciales de la comunidad, que han de respetarse en un momento y sociedad concreta, y que limitan la autonomía de la voluntad de las partes; y la seguridad entendida como derecho subjetivo y fundamental de las personas y que el Estado está obligado a proporcionar y facilitar, determinando las amenazas y las capacidades para neutralizarlas.

La seguridad impuesta en el ejercicio de la soberanía constituye el Orden Público tradicional o antiguo y cuya expresión se puso de manifiesto en las Pragmáticas y Leyes de Orden Público.

En España, con la Constitución de 1978 las personas tienen reconocidos como derechos fundamentales el de la libertad y el de la seguridad. Y la seguridad pública o seguridad ciudadana, de titularidad difusa pero que permite y afecta a la seguridad individual, es competencia exclusiva del Estado y se ejerce a través de las Fuerzas y Cuerpos de Seguridad. Las dos leyes de protección de la seguridad ciudadana responden a esta acepción del orden público, como derecho y protección del ejercicio de los derechos y libertades fundamentales que implican y exigen una tranquilidad material para poder ejercitarlos.

Los cambios normativos producidos por la Ley Orgánica 4/2015 de 30 de marzo son de muy escasa importancia y, fundamentalmente, se regula la misma materia y de la misma forma. La regulación de los 
registros corporales externos, en el ámbito administrativo, constituye una de las innovaciones. También el límite máximo del tiempo invertido para la identificación personal con traslado a dependencias policiales. Las alteraciones de la seguridad ciudadana, con riesgo para personas y bienes, producidas como consecuencia de reuniones o manifestaciones celebradas en las inmediaciones de las cámaras legislativas, considerada como infracción grave, podrían recogerse en las infracciones genéricas de tal naturaleza. El uso de video-cámaras por los miembros de las Fuerzas y Cuerpos de Seguridad no sufre variación alguna y, únicamente se incorpora la infracción grave del uso público e indebido o no autorizado de imágenes que puedan poner en peligro la seguridad personal o familiar de los agentes, matizando la ley que con el respeto al derecho fundamental a la información.

Se señalan, por primera vez, las instalaciones consideradas básicas para la comunidad ${ }^{70}$, y se incorpora un procedimiento abreviado, para las infracciones graves y leves, con reducción de la sanción a la mitad y carácter voluntario del afectado.

El rechazo en frontera, de aplicación exclusivamente, en las de Ceuta y Melilla, para impedir la entrada ilegal en territorio español de los extranjeros que intenten burlar los elementos de contención fronterizos, parece más razonable que afirmar que se les permita la entrada ilegal en España. Queda a salvo la legislación internacional humanitaria que deberá ser invocada y solicitarse en los puestos habilitados a tal fin.

En coherencia con la legislación de menores se excluye de la aplicación de la ley a los menores de 14 años.

Finalmente cabe resaltar la obligación de los agentes de comunicar a las personas afectadas por la ley, el motivo de la identificación, cacheo o registro, así como, en su caso, del traslado a dependencias policiales, donde a la salida se le dará recibo acreditativo del motivo de la identificación, del tiempo invertido y de la identidad del agente que haya adoptado la decisión.

\footnotetext{
${ }^{70}$ a) Centrales nucleares, petroquímicas, refinerías y depósitos de combustible.

b) Puertos, aeropuertos y demás infraestructuras de transporte.

c) Servicios de suministro y distribución de agua, gas y electricidad.

d) Infraestructuras de telecomunicaciones.
} 